\title{
The Critical Reception of Gjergj Fishta during 1944 - 1990
}

\author{
Dr. Lili Sula \\ Faculty of History and Philology \\ Departament of Literature, University of Tirana
}

\section{Doi:10.5901/ajis.2013.v2n3p99}

\begin{abstract}
Gjergj Fishta is one of the most important writers of Albanian literature. He holds a central place in the Albanian literary system. Until 1990s, his work was censured creating a typical reception model in our literature at the time; that is the critical ideological reception. The critical reception of Fishta's work during (1944 - 1990) presents a typical phenomena of a malfunctioning of the scheme of communication and circulation of the artistic value. The literary and religious activity of Gjergj Fishta was anathematized. It was the totalitarian regime's policy and practice to attack any deviation from the socialist realism platform and/or any religious activity and practice of various religions representatives. What generally characterizes the critical judgment of this period is a poor qualitative and quantitative judgment, the homogenization of the critical reception of the author's work according to the ideological reception model and the axiomatic formulation of the conclusions without doing an analytical interpretation. The critical reception of Fishta's work in this period presents one of the anathemized models of the reception of the author, a typical ideological reception model, which had quite a significant impact in the Albanian literary system.
\end{abstract}

Gjergj Fishta is one of the most important writers of Albanian literature. He holds a central place in the Albanian literary system. Until 1990s, his work was censured creating a typical reception model in our literature at the time; that is the critical ideological reception.

Fishta's critical reception is presented as a curve-diagram starting in $1905^{*}$, reaching the peak point in 1943 extended until 1944 (period I), marking a steep decline after 1946- 1947 until 1990 (period II), followed by a new rise in the same year (period III, 1990s and onwards).

The second phase of the critical reception of Fishta's work (1944 - 1990) presents a typical phenomena (which can even be considered as a specific model) of a malfunctioning of the scheme of communication and circulation of the artistic value. The literary and religious activity of Gjergj Fishta was anathematized. It was the totalitarian regime's policy and practice to attack any deviation from the socialist realism platform and/or any religious activity and practice of various religions representatives.

The theories of literary communication show that the de-codification (the third instance of literary communication) has an important role, even determinant, in the circulation of a literary work (of the artistic value at large). The normal scheme of artistic communication functions as a correlation between the writer/emetues, (the codifier), the work (as a sign system arrangement) and the reader (the receptor or de-codifier). But during the period $1944-1990$, Fishta and his work were violently attacked, consequently the receptor totally detached the relation with the works of this author, while his critical receptor was being abandoned/extra-letrarized under "the auspice" of the head of the future state himself. That marked the creation of the ideological reception model, which would soon be used as a reference for many other authors of our literature. In 1947, after a visit in Bulgaria, E. Hoxha said: "The enemies of our people had embedded in the system the decayed bourgeois sense of chauvinism and nationalism and traitors and spies like Gjergj Fishta and others have worked all their life to separate us from and create enemies with those people... [meaning the Slav people, - L.S.) ${ }^{1}$

Two years later, in a meeting of the Political Bureau of the Central Committee (CC) of the Labour Party of Albania (LPA), (7 June 1949) with the subject: Our literature to walk on the path of the socialist realism the former leader stated:

\footnotetext{
" Research shows that the first publication on Gjergj Fishta dates back in 1904 (Referece to the section nel clero cattolico Albanese of the newspaper "La nacione albanese", Pallagorio, 15 April 1904), while the first critical reception for his work dates back to 1905, when the first edition of Lahuta e Malcise was published. The newspaper "La nazione Albanese", Pallagorio 15 April 1905, under the section "New books", announces through a review the publication of the book consisting of 5 cantos.

1 The Albanian Delegation headed by the General Colonel E. Hoxha returned to Tirana: "Bashkimi" Tirana, p.1, 20 December 1947
} 
"But in my view - E. Hoxha said, - Fishta and his satires are nothing as compared to "Epopeja e Ballit Kombetar" of Shefqet Musaraj. The works/books of our comrades who write about the war, the life and work of our people stand higher; they are of a healthy content." 2 In those years, the publication or re-publication of the works of this author were banned; they were of restricted use in the libraries, and could be read and used only by authorized persons. Synchronically, the history of Fishta's reception started to be created as a segment to be avoided, ideologically deviating from its diachronic predecessor. The ideological preface sets the tone of the whole spectrum of the horizon of anticipation (reception). The criticism as the highest level of the horizon of anticipation and interpretation not only did not match with the work but also presented it with deviation or even entirely overthrown. Even in those rare occasions, when the criticism touched upon his work it was very briefly and with the intention to throw mud on it. Therefore, the scheme of normal circulation of aesthetic value was attacked and taken away from the literature; creating the ideological reception.

What generally characterizes the critical judgment of this period as compared with the other two periods of Fishta's critical reception is a poor qualitative and quantitative judgment, the homogenization of the critical reception of the author's work according to the ideological reception model and the axiomatic formulation of the conclusions without doing an analytical interpretation.

Note some statistical data:

Period I (1905 - 1944) includes 2 collections with studies, 4 study books, 3 special editions of literary and cultural magazines and 517 articles in the periodical publications at the time. J. Rrota, F. Cordignano, P. Bardhi, M. Sirdani, B. Palaj, etc. are some of the personalities that dealt with Fishta and his artistic works.

Period II (1944 - 1990) includes 5 study books, 2 of which were published (T. Kolgjini Shpalime rreth Lahutës, M Lambertz Gjergj Fishta und das albanische heldenepos, 1 special edition of the literary and artistic magazine Shejzat, 189 articles in various periodical publications of the time.

In this period three other books were written, but for well-known reasons they were not published: (B. Dema: Fjalori historik i veprës "Lahuta e Malcis" (The historical vocabulary of "The Highland Lute"), Shkodra, 1945, [manuscript]; V. Bala Gjergj Fishta: Jeta dhe vepra (Fishta: his life and work), Shkodra, 1961; A. Gjyli Atë Gjergj Fishta, çakall i kishës katolike shqiptare (Father Gjergj Fishta jackal of the Albanian catholic church), Tirana, 1972 [manuscript]).

Period III (1990 onwards) includes 23 publications of monography and studies, 7 collections of different studies and over 1000 reviews, articles, researches and studies published in various present periodicals.

As per our research, the following years of Period II: 1948, 1952, 1953, 1954, 1963, 1977 and 1988 are considered as blank periods without any publication on Fishta or his work. The critical reception of Fishta intentionally or not was silent, not serving the ideological expectations.

${ }^{2}$ Note: Our literature to walk on the path of the socialist realism. Discussion in the meeting of the Political Bureau of the CC of the LPA, 7 June 1949); published in E. Hoxha: Vepra. Volume. 9.- Tirana: Naim Frashëri, 1971, p. 190.

However, during this period Fishta's work continued to be receptive. Although it may sound strange, in those years there was a revival of the reception, which was to a certain level similar to the reception of The Highland Lute by the population of the highlands in 1920 - 1930. The poem was verbally transmitted to others and many of its lines were learned by heart. Certainly, the regime at the time could not entirely control and prohibit the special pieces of Fishta's publications be secretly circulated by people hand to hand. In our opinion, this is one of the rare cases in literature when the verbal reception functions as an esthetic reception. In such a way, part of the author's satire and a smaller part of his lyrics have been circulated. This kind of circulation was a silent opposition with the ideological model and matched with the author's work creating in this way the most normal horizon of Fishta's work for the period.

The critical reception of Fishta's work during Period II developed in two directions, completely different in essence: the official Tirana (Dh. Shuteriqi, K. Bihiku, Sh. Musaraj etc.) that represent a denigrating and censuring stand towards Father Fishta. With some insignificant differences, the Kosova literary personalities maintained the same stand. Meanwhile, a horizon of special anticipation, which was chronologically a continuation of the critical reception of 40s and that would match Fishta's work, would include the critical reception of diaspora (E. Koliqi, M. Camaj, Z. Valentini, D. Gjeçaj, L. Shantoja etc.).

I would like to mention some of the titles: K. Bihiku: Fishta si përfaqësues i letërsisë klerikale (Fishta as a representative of clerical literature); Dh. Andoni: Një dokument që demaskon fytyrën e Patër Gjergj Fishtës (A document that takes off the mask of Father Gjergj Fishta); lliaz Gogaj: Mbi qendrimin reaksionar të klerit në fushën e arsimit (On the reactionary stand of clericals in the field of education), Ramiz Kelmendi:

Gomari i kuvendit polemika në letrat shqipe (The donkey of discussions, the polemics of the Albanian literature); Rakip Beqaj: Veprimtaria antikombëtare e klerit katolik shqiptar (The antinational activity of the Albanian catholic clergy); Jusuf Ferizi: Në shërbim të ideologjisë së Papës (At the service of Pope's ideology); Viron Koka: Ideologjia reaksionare e klerit 
në vitet'30 të shekullit XX (The reactionary ideology of the clergy during 1930s); A. Gjyli: Atë Gjergj Fishta çakall i kishës katolike shqiptare. Vepra letrare dhe politika e Fishtës hymn imperializmit italian dhe pushtuesve fashistë (Father Gjergj Fishta jackal of the Albanian catholic church. Fishta's literary work and politics, an anthem to Italian imperialism and fascist occupiers.)

The typical ideological reception model can be found in the official texts of Historisë së Letërsisë Shqiptare (The history of Albanian literature), published by a group of scholars from the Academy of Science in Tirana in 1983, which left entirely out Fishta, Koliqi, Prenushi and partially Poradeci and Kuteli. "For him, - this history text says, - the interests of church and religion stood above the interest of the nation and the people, which he used to declare and defend using his demagogy and also using his satire as the basis of his literary work. His main work, the epic poem "The Highland Lute" by attacking the chauvinism of northern neighbors, propagated anti-Slavism and ignoring the fight against ottoman occupiers. It was an anthem to patriarchalism and bajraktarism, the religious and clerical obscurantism ..." while regarding the Donkey of Babatasi these scholars state: "It is very often accompanied by the prolixity, the rhetoric, the brutality in expression and style, up to banality, their false argumentation trying to forcefully impose, as well as an obvious conservative stand towards linguistics."

In addition to these opinions, in Albania during the first years of the communist regime efforts were made to keep a moderate stand towards Gj. Fishta, which however did not last long. In this respect, it is to be noted the speech of S. Malëshova and Y. Dishnica in the Third Conference of the League of the Writers of Albania, (1949) against "the demarcation line in literature."4 Followed later by the unfinished project (found in the Archive of the Institute of the Linguistics under the Academy of Science in Tirana), ${ }^{5}$ of a group of scholars that worked on the Volume III of the History of Albanian Literature, whereby Fishta was dedicated a special chapter, which was more informative, descriptive and less analytical.

The Diaspora writers such as E. Koliqi, G. Gradilone, Z. Valentini, K. Gurakuqi, M. Camaj, T. Kolgjini, P. J. Marlekaj, A. Pipa, Pal Duka Gjini etc. as well as the scholar in the Albanian language and literature, M. Lambertz are the personalities whose contribution constitute the most important criticism in literature of that period.

At the time, The Highland Lute was published by Gjeçaj in Rome in 1958. Koliqi translated it in Italian and in 1973 published the melodrama Jerina ase mbretnesha e lulevet (Jerina or the queen of flowers) in Italian. In Leipzig (1958), M. Lambertz published The Highland Lute in German, while in 1949 (in Laipzig) published the study Gjergj Fishta and the Albanian Epic (Gjergj Fishta und das albanische heldenepos Lahuta e Malcis)

Below are some of the titles of publications/studies as compared to those published in Tirana: Petrotta: Mësonjësi arbëresh dhe nxënësi shqiptar. At Leonardo de Martino dhe At Gjergj Fishta (The arberesh teacher and the Albanian student. Father Leonardo de Martino and Father Gjergj Fishta); M Camaj: Shëndrrimi e përpunimi i thanjeve në "Lahutën e Malcis" (Transforming and processing of phrases in "The Highland Lute"); Xh. Gradilone: Ndikime të klaasicizmit në veprën e Fishtës (The impact of classicism in Fishta's work) as well as the formal studies of Angela Cirrincione or others.

In 1969 in Istanbul Tahir Kolgjini, ${ }^{6}$ alias Lok Limthi, published Shpalime rreth Lahutës, a glossary with explanations

\footnotetext{
${ }^{3}$ Historia e Letërsisë Shqiptare (The history of Albanian literature)- Academy of Science, Tirana, 1983, p.470, 471.

${ }^{4}$ In the discussion session, Sh. Musaraj in his speech: S. Malëshova is against the conference, said: "S. Malëshova is not in agreement with the referred "demarcation line" between the writers of the advanced tendency and those of reactionary tendency in the Albanian literature; he does not agree that "Fishta and Mjeda be placed in two separate camps, that Faik Konica and F. Noli do not share the same path" and tried to present Fishta as an advanced writer." Reference: 3rd Conference of the League of the Writers of Albania (9-12 October 1949).- Tirana, 1950, p. 58.

${ }^{5}$ In the Archive of this Institute, there are two monographies on Gj. Fishta, which we would like to refer to even though they are in a manuscript form since they were circulated among the scholars at the time. The monography by V. Bala, Gjergj Fishta (1871-1940), Tirana, 1961, (published with some changes by his son Agron Bala in Tirana in 1998) aiming at being comprehensive and having a historical-cultural objective focuses on the bio-social data when talking about the life and the work of the author, making informativedescriptive interpretation when talking about his literary work, poetry, satire, epics, drama, prose. It focuses less on the artistic characteristics of the work of the poet, e.g. when he speaks about his artistic mastery. The manuscript of A. Gjyli, Atë Gjergj Fishta çakall $i$ kishës katolike shqiptare (Father Gjergj Fishta jackal of the Albanian catholic church), Tirana, 1972, presents the model of official critical reception to censure and anathemize Fishta's work. Some of the chapters are: Fishta's literary work and politics, an anthem to Italian imperialism and fascist occupiers; Fishta's conceptual viewpoint on the enemies of the Albanian people; Historical falsification and deformation; The catholic clergy "The only leader of the Albanian people"; The opium for the people, etc.

${ }^{6}$ T. Kolgjini's linguistics interests started since 1961 with the study Fjalët turkisht ose t'ardhuna me anën e turkishtes të përdorura në Lahutën e Malcis (Turkish words or loaned words through Turkish language used in the Highland Lute), published in "Shejzat", Roma, 1961, no. 3-4, p. 86-92; no. 5-6, p. 161-165; no. 9-10, p. 326-335.
} 
of a lexicology and idiomatic nature created the basis of the successive studies on the work of the poet.

The deviations of the horizon of anticipation, the opposite expectations between two schools, the Official Tirana and the one of Diaspora are obvious.

The articles published by Z. Nekaj and K. Gurakuqi, etc. denounce the censure of Fishta in Albania. In his article Fishta pâ emën në tekstet e shkollavet të Shqipnis(Fishta without a name in the school texts in Albania), Z. Nekaj notes that the text Gramatika e shqipes (The Albanian grammar)(1949) by K. Cipodoes include parts from Fishta's work, but as an anonymous without referring to the author. Nekaj and K. Gurakuqi find the reasons for the censure of Fishta's work in the policy of the Albanian regime at the time. K. Gurakuqi in Pse kaq mëni kundra Fishtës (Why so much rancor against Fishta) states two reasons for the censure of Father Fishta'work "In Fishta's entire work, that will never die, it becomes obvious the love for the homeland of the ancestors and the hatred against Slavic-Montenegro, which was unhappy with the independence of Albania. This is one of the main reasons for the despise they want to impose on Fishta's work..... Fishta is also despised for one more reason: in odium fidei. Our poet was also a man of religion. "Religion and Homeland" was his motto as well as that of the brothers, the Albanian Franciscan Friars..."

Another direction to be considered when looking into Fishta's ideologic reception is the geography of the publications.

Should we consider R. Escarp*s concept on the sociology of literature, we note that the reception of Fishta's work during the second phase was also published in the form of the announcements, memoires, articles, studies, etc., in the periodical organs such as Bashkimi", "Rinia", "Zëri i popullit", "Flamuri", "Shejzat", "Dielli", "Buletini Katolik Shqiptar", "Shqiptari i lire", "Dobri Pastir", "Shkodra", "Mësuesi", "Zeitschrift fūr Balkanologie", "Koha Jonë", "Drita", "Zjarri", "Zëri i Popullit", "Rilindja", "Gjurmime albanologjike", etc., that were published in Tirana, Shkodra, Prishtina, San Francisco, Roma, Leipzig, Moscow, New York, Muenchen, Milano, Boston, Stuttgart, Istanbul, Sarajevo, Paris etc.

Even without referring to the authors of the articles of the above-listed publications, their a/ideological typology can be easily defined.

The critical reception of Fishta's work in the second period presents one of the anathemized models of the reception of the author, a typical ideological reception model, which had quite a significant impact in the Albanian literary system.

\section{References}

Bala, Vehbi: Gjergj Fishta (1871-1940), Tirana, 1961, (manuscript).

Escarpit, Robert: Sociologia della letteratura, Napoli, 1977.

Gradione, Giuseppe: La letteratura albanese e il mondo classico, Roma,1983.

Gjyli, Arif: Atë Gjergj Fishta, çakall i Kishës Katolike Shqiptare (Father Gjergj Fishta jackal of the Albanian catholic church), Tirana, 1972, (manuscript).

Kolgjini, Tahir : Shpalime rreth Lahutës, Istanbul, 1969.

Konferenca e III-të e Lidhjes së Shkrimtarëve të Shqipërisë (Third Conference of the League of the Writers of Albania) (9-12 October 1949), Tirana, 1950.

Shejzat, Roma, 1961, no. 11-12.

Todorov, Tzvetan: Letërsia në rrezik (Literature in danger), Prishtina, 2007.

"Note: Robert Escarpit: Sociologia della letteratura,- Napoli, 1977. 